\title{
The Relationship between Course Management and Examination Attrition Rates among Undergraduate Medical Students at the University of Zambia
}

\author{
Harrison Daka, Sekelani S. Banda \\ and Charles M. Namafe
}

\begin{abstract}
This study investigated the relationship between course management and examination attrition rates among undergraduate medical students at the University of Zambia's School of Medicine between 2008 and 20I6. An explanatory sequential research design was used for data collection and data were gathered using a survey instrument, focus group discussions and interviews with key informants. The quantitative data from the first set were analysed using descriptive and inferential statistics while the qualitative data from the second set were analysed using the constant comparative method. The findings indicate that there was a significant statistical difference in the course workloads in all programmes $(\mathrm{p}=0.000, \mathrm{~F}=4,596$, $\mathrm{d} f=8.53)$. The course loads were heavy, with little time allocated to them. Course concepts were not taught in depth, resulting in student perceptions that the courses were difficult. The findings point to the urgent need to revise or review the course content of several programmes to align it with the time allocated. Furthermore, the Department of Medical Education and Development should consider organising specific pedagogical training programmes for existing and newly-employed academic staff.
\end{abstract}

Key words: quality education, attrition rates, course management

ABOUT THE AUTHORS: HARRISON DAKA The University of Zambia. Email: bhamudak@ yahoo.com

SEKELANI S. BANDA The University of Zambia. Email: ssbanda2007@gmail.com

CHARLES M. NAMAFE The University of Zambia. Email: mnamafe@unza.zm 
Cette étude a mené l'enquête sur la relation entre la gestion des cours et le taux de déperdition aux examens parmi les population étudiante en premier cycle de médecine à l'Ecole de Médecine de l'université de Zambie entre 2008 et 2016 . Une conception de recherche séquentielle et exploratoire a été utilisée pour la collecte de données et les données ont été rassemblées en utilisant un instrument d'enquête, des groupes de discussion, ainsi que des entretiens auprès des principaux intervenants. Les données quantitatives de la première série ont été analysées en employant des statistiques déductives et descriptives alors que les données qualitatives de la deuxième série ont été analysées en utilisant la méthode de comparaison constante. Les résultats indiquent qu'il y avait une différence statistique considérable dans la charge de travail impliquée par les cours dans tous les programmes $(\mathrm{p}=0.000, \mathrm{~F}=4,596, \mathrm{~d} \mathrm{f}=8.53)$. La charge de travail était lourde, avec peu de temps dédié aux cours. Les concepts des cours n'étaient pas approfondis, ayant pour conséquence dans la perception des étudiant.es que les cours étaient difficiles. Les résultats soulèvent le besoin urgent de revoir ou réexaminer le contenu des cours de plusieurs programme pour l'aligner avec le temps alloué aux cours. En outre, le Département de l'Education et du Développement Médical devrait considérer l'organisation de programmes de formation pédagogique spécifiques pour le personnel académique récemment embauchés.

Mots clés: éducation de qualité, taux de déperdition, gestion des cours

\section{Background and Context}

The University of Zambia's School of Medicine has maintained exceptionally high educational standards including quality instructional design, leading to the production of competent graduates. However, from 2008 to 2016 there were high examination attrition rates among undergraduate students in various programmes (Daka, 20I9). Attrition is defined as a student's departure from the school or possible departure from the entire educational system (De Remer, 2002). This study measured educational quality at the School of Medicine by analysing the relationship between course management and examination attrition rates. The university selects students based on merit. The medical school admits the highest performers from the School of Natural Sciences, which offers places to the best applicants from secondary schools. However, as Table I illustrates, it still recorded high examination attrition rates and low student grade point average (GPA) for the period 2008 to 2014 .
Table 1. Examination Attrition Rates (\%) of Various Programmes from 2008 to 2014

\begin{tabular}{|l|c|c|c|c|c|c|}
\hline Programme & 2008 & 2009 & 2010 & 2011 & 2013 & 2014 \\
\hline $\begin{array}{l}\text { BSc Environmental. } \\
\text { Health }\end{array}$ & 6.67 & 0.00 & 6.25 & 8.75 & 4.00 & 14.7 \\
\hline BSc Physiotherapy & 7.50 & 20.00 & 21.50 & 6.50 & 25.0 & 10.0 \\
\hline $\begin{array}{l}\text { BSc Biomedical } \\
\text { Sciences }\end{array}$ & 0.00 & 4.33 & 12.30 & 6.00 & 19.0 & 41.0 \\
\hline BSc pharmarcy & 0.00 & 15.50 & 12.00 & 15.00 & 18.0 & 29.0 \\
\hline MBChB & 1.00 & 30.00 & 14.00 & 17.00 & 12.0 & 30.0 \\
\hline Average & 3.03 & 13.97 & 13.21 & 10.65 & 15.60 & 24.94 \\
\hline
\end{tabular}

Source: Daka (2019)

Examination attrition is one of the quality outcomes employed to determine the educational quality of a learning institution (James and Chilvers, 200I). Debate continues on the academic factors that contribute to attrition and these are likely to vary from one setting to another. Moore and Shurock (2006) assert that the examination attrition rate is a major indicator of quality that impacts student retention. When more students progress to the next year, the retention rate is usually higher (Jones, 2008), with the converse also true.

Despite decades of research on this phenomenon, attrition remains one of the most complex and least understood problems confronting educational institutions (Bean, 2005). Defining attrition, and the factors behind it, and developing potential solutions are concurrent priorities in education theory and application (Sarrico, 20I6). Thomson (I999) and Wild and Ebbers (2002) highlight that a high attrition rate indicates that an institution has an educational quality problem. As a result, universities are becoming more aware of and accountable for graduation rates while they seek to ensure quality education (Reason, 2009). Reason (2009) adds that policy makers in most states use retention and graduation rates as performance indicators for higher education institutions.

Research on the causes of high examination attrition rates is generally contradictory and largely inconclusive (Bean and Metzner, 2006). Furthermore, there is no consensus on the most appropriate theoretical model to promote quality education. Pascarrella and Terenzini (2005) argue that variables relating to course management are the main causes of examination attrition, while Wild and Ebbers (2002) point to teaching characteristics and institutional characteristics as major contributors. One of the few things scholars agree on is the importance of studying and improv- 
ing retention (Wild and Ebbers, 2002). This study aimed to contribute to this quest by examining the relationship between course management and examination attrition among undergraduate students at the University of Zambia's School of Medicine. Course management was one of the concerns raised by students in the annual evaluation conducted by the school.

\section{Problem Statement}

Since 1995, the School of Medicine has launched initiatives aimed at improving the number and quality of graduates. These include staff capacity building, increasing the number of lecturers, and an improved learning environment as well as increased access to educational resources. Despite these efforts, examination attrition rates remain high.

\section{The Relationship between Quality Education and Quality Outcomes}

Numerous studies have identified educational quality as an important predictor of educational success or quality outcomes (Dockter, 200I; Sulaiman and Mohezar, 2006; Susan, David and Deborah, 20II; Kaynak, 2003). Such research has utilised both factual data (Reason, 2009) and perceptual data (Dockter, 200I), with data analysis based on a series of multiple regressions (Pascarella et al., 2005) and correlations (Curkovic and Ickery, 2000). However, few empirical studies have been conducted on the direct and indirect effects of quality education on student performance.

Two exploratory studies by Kaynak (2003) in the United States (US) on Total Quality Management (TQM) examined these direct links using structural equation models and educational quality as a multidimensional construct. The findings showed that the two major quality outcomes were GPA and examination attrition rates. The correlation between these two variables indicates that quality education results in high levels of student performance. Thus, if courses are well managed, and there are quality teaching and sound assessment processes, examination attrition rates should be low as many students should perform well with high GPAs (Schindler, Puls-Elvidge, Welzant and Crawford, 20I5; Pokorny and Warren, 20I6; Bateman, McCracken, Thomason and Ellis, 20I6).

\section{The Relationship between Educational Quality and Examination Attrition}

\section{Rates}

The terms low retention rates, low graduation rates and high examination attrition rates are used interchangeably in this article as they carry the same meaning. Identifying the predictors of academic failure and success is important for medical schools that seek to ensure high completion rates and develop support mechanisms for students who do not perform well. High examination attrition rates have been attributed to various factors, including quality content, a quality learning environment, quality process and quality learners.

Students' performance in standardised tests points to a strong link between attrition and educational quality (Billings and Halstead, 2005). This suggests that examination attrition rates are one of the most important indicators to measure student performance. Smith (2009) notes that high examination attrition results from cognitive overload. The author's research among nursing students in the US revealed that most of the causes of attrition were academic in nature (Smith, 2009), including failure to meet academic standards, students quitting due to academic difficulties and a lack of academic staff trained in methodology.

Mashaba and Mhlongo (2003) found that the attrition rate, or what they called "wastage" was between I $8 \%$ and $50 \%$ in South African nursing schools Their surveys of students who dropped out of university-affiliated nursing schools revealed that 90\% were first generation college students. The causes included questionable teaching practices, which did not promote critical thinking, and the fact that lecturers spent much of their time working in private hospitals, resulting in many lessons being cancelled, too little time being set aside for student consultations, and a lack of detailed feedback. Students' poor performance in examinations contributed to high attrition rates (Mashaba and Mhlongo, 2003).

Balon, Alpert, Cluver and Lewis (2013) examined student attrition rates in a Canadian nursing programme. The study targeted all I59 students in a nursing programme between 1996 and 1998 . Of the 69 who responded to the questionnaire, $48(69.6 \%)$ were still in the programme, I2 (I7.4\%) had left the programme, and nine (I3.0\%) were progressing behind their original class. Thus, more than $30 \%$ were either not going to graduate or not going to graduate on time. The factors contributing to the high attrition rates included a heavy course workload and lecturers' failure to explain difficult concepts.

Jones' (2008) research on attrition rates among medical students at the University of Nottingham in the United Kingdom between I970 and I995 covered 2270 students. The study found that $6.5 \%$ of the students had left the programme before graduating due to failing their examinations. Students cited being ill-prepared for the final examination as the cause. Jones (2008) thus concluded that educational quality was one of the academic factors that led to some students not graduating on time. The author adds that educational quality is an essential component in enhancing and maintaining the quality of teaching and learning.

Grant (20I2) likened education to a service industry where quality is considered at both production level (the creation of appropriate medical graduates) and perceptual level (maintenance of institutional values and 
principles). The production level involves how teaching and learning take place. It includes management of courses, teaching characteristics and assessment processes. The perceptual level relates to how the institution ensures that its values and principles are upheld.

One of the educational quality variables cited in the above studies is mismanagement of courses which is the focus of this article. Scholars posit that well-managed courses and sound assessment practices will result in low examination attrition rates. Bean (2005) and Frankola (200I) identify inadequate time for learning, poorly designed courses and incompetent instructors as causes of high attrition rates and low GPA. Establishing why students fail is critical in determining the quality of services and delivery methods of a particular learning institution (Bean, 2005), as the predictors might be different in different settings.

There is consensus in the literature that quality content and quality processes are the main predictors of student performance in examinations (Mirchandani, Lynch and Hamilton, 2009). Terry (2008) developed a model based on a production view of student learning to examine the determinants of examination performance among students taking a business major. The findings were consistent with much of the previous research in this area, in that institutional input and course management made a strong contribution to academic performance as measured by GPA and attrition.

\section{The Concept of Course Management}

This study used Biggs and Tang's (2007) theory of constructive alignment, which highlights the shift from teacher delivery to student learning. It asserts that learning is a product of the student's activities and experiences rather than the lecturer's. The emphasis is on what students can actually do at the end of the learning experience. It is also important that the learning outcomes, the teaching and learning activities, and assessment are aligned (Biggs and Tang, 2007), as this promotes compatibility and consistency. When these three elements work in synergy, the learning outcomes drive curriculum design, with the other elements including teaching and assessment falling into place.

In order to sharpen the focus of higher education on student learning outcomes, it is important to go beyond tinkering with traditional structures and methods and undertake a paradigm shift in educational philosophy and practice. Traditional curriculum design focuses on the teacher's input and on assessment of how well students absorb the material taught. In contrast, student-centred approaches emphasise what students are expected to be able to do at the end of the learning experience.

Swail (2004) highlights the need for an on-going process of curriculum review and revision. Indeed, this should be a mainstream component of curriculum development. Academic content should reflect the current dynamics of industry trends and practice as well as anticipated practices and procedures, for example, cutting-edge technology and research, especially in the fields of science, medicine and nursing (Kuhn, 2006; Mirchandani et al., 200I).

Learning institutions should develop an integrated curriculum review process to ensure that all aspects of the curriculum are up-to-date and relevant to society's needs (Black, Harrison, Lee, Marshall and Wiliam, 2004). At many universities, individual faculty members decide what to include in a course syllabus, leaving much to be desired in terms of quality control. This issue is important given that most faculty have little or no background in learning theory or educational practice (Biggs and Tang, 2007). Therefore, a systemic and cyclical review process that enables faculty to review all curricula on a rotating basis helps to control the content delivered in classes.

The way the curriculum is developed has the greatest effect on examination attrition. This includes the bulkiness of the course, the time allocated to it, practical activities included and the relevance or applicability of the course. Kane, Rockoff and Staiger (2006) state that students' level of understanding of the course content contributes to their GPA. Biggs and Tang (2007) and Black et al. (2004) assert that a poorly structured course contributes to low GPA. A pertinent question is whether or not current courses were developed based on needs assessment. If so, how often have they been reviewed and after how long? How interlinked are the concepts from one level to another? The current study focused on the four variables identified by Cherif, Movahedzadeh, Adams and Dunning, (2013), namely, the bulkiness of the course, the time allocated to it, time spent on the course and its level of difficulty. No systematic research has been conducted on the links between examination attrition in tertiary education and course management in Zambia.

\section{Research Methodology and Design}

This study used an explanatory sequential design and mixed methods to gather and analyse the data. In such a design the researcher begins with a quantitative phase followed by a qualitative phase that examines the initial results in depth (Subedi, 20I6).

The sample comprised of 16 key informants and 780 students from the University of Zambia's School of Medicine. The total sample size was therefore 796,65 of whom were enrolled in the Nursing Sciences programme, where a pilot study was carried out, with the remainder from the other five departments (MBChB, Pharmacy, Biomedical Sciences, Physiotherapy and Environmental Health) where 6or questionnaires were administered. 
A census method was used with the students to reduce sampling errors and to provide a true measure of the population while purposive sampling was used to select key informants in order to collect detailed and appropriate information. Analysis of relevant documents and the questionnaires ensured methodological triangulation (Kombo and Tromp, 2006).

The closed-ended questions in the questionnaire focused on measuring how the courses in the School of Medicine were managed. In-depth interviews as well as focus group discussions were conducted with purposively selected key informants. The interviews focused on course characteristics while the focus group discussions related to how courses were managed to assess needs, develop interventions, test new ideas or improve existing programmes. Participation was based on informed consent and was voluntary, with the right of withdrawal at any time (Njobvu, 20I5). The pilot study ensured internal and external reliability of the research instruments, while the trustworthiness of the qualitative data was ensured through credible, dependable and confirmable means of data transfer. The validity and reliability of the quantitative data was ensured through pre-testing and review of the instruments by medical education experts and computation of the Chronbach's alpha of $0.94(\alpha)$ value. The data was analysed using descriptive analysis, one-way ANOVA, Chi-square, measurement of association and comparative methods. Direct quotes are used to promote authenticity.

\section{Findings}

Students' Perceptions of Course Management

The descriptive statistics, including frequencies and percentages of the respondents' perceptions of course workload, the pace of study, level of difficulty and time spent on the course are presented in Table 2.

Table 2. Characteristics of Course Management

\begin{tabular}{|l|c|c|c|c|}
\hline $\begin{array}{l}\text { Programme } \\
\text { of Study }\end{array}$ & $\begin{array}{c}\text { Course } \\
\text { Workload \% }\end{array}$ & $\begin{array}{c}\text { Pace of the } \\
\text { Course \% }\end{array}$ & $\begin{array}{c}\text { Level of } \\
\text { Difficulty \% }\end{array}$ & $\begin{array}{c}\text { Time spent } \\
\text { on Courses \% }\end{array}$ \\
\hline Average & 82 & 71 & 65 & 63 \\
\hline
\end{tabular}

Source: Field data, 2018

The table shows that, most of the students $(82 \%)$ perceived the course workloads as heavy. The pace of the course was felt to be fast with a response rate of $71 \%$. The level of difficulty of the course was perceived to be high $(65 \%)$, while $63 \%$ of the students felt that a large amount of time was spent on a course.
Relationship between Students' Perceptions of Course Management One-way ANOVA tests were conducted to compare the students' responses with regard to the different programmes.

Table 3. ANOVA Values of Course Management

\begin{tabular}{|l|l|c|c|c|c|c|}
\hline Characteristics & N & $\begin{array}{c}\text { Mean } \\
\text { Score }\end{array}$ & SD & Df & F & Sig. \\
\hline Course Workload & 601 & 1.63 & .71 & $\begin{array}{r}596 \\
4\end{array}$ & 8.83 & .000 \\
\hline Pace of the Course & 601 & 2.10 & .93 & 596 & 8.46 & .000 \\
\hline Level of Difficulty & 601 & 2.52 & .69 & $\begin{array}{r}596 \\
4\end{array}$ & 1.11 & .349 \\
\hline $\begin{array}{l}\text { Time Spent on the } \\
\text { Course }\end{array}$ & 601 & 2.77 & .99 & 596 & 1.41 & .228 \\
\hline
\end{tabular}

*Significant at $\rho<.05$

Source: Field data, 2018

The course workload and the pace of the course were statistically and significantly different among the course management factors with $[\mathrm{F}(4,596)$ $=8.83, \rho=0.000]$ and $[\mathrm{F}(4,596)=8.46, \rho=0.000]$, respectively. These results show that the students' views differed significantly, suggesting that the course workload in different courses and programmes differed with the pace at which the courses progressed. In terms of the other two variables, level of difficulty and time spent on the course, the results showed that the groups did not significantly and statistically differ, with F $(4,596)$ $=$ I.II, $\mathrm{p}=.349$ at $\mathrm{p}<0.05$ and $\mathrm{F}(4,596)=\mathrm{I} .4 \mathrm{I}, \mathrm{p}=.228$ at $\mathrm{p}<0.05$, respectively. This suggests that, despite the differences in the programmes and courses, students' perceptions with regard to these issues were not statistically different.

Document analysis revealed the relationship between the courses which were perceived to be well-managed and those that were regarded as poorlymanaged, and examination attrition rates. 
Table 4. Well-managed Courses

\begin{tabular}{|l|c|}
\hline Course Code & Attrition Rate (\%) \\
\hline PMY 3410 & 2.5 \\
\hline PTM 3010 & 0.0 \\
\hline PSY 6410 & 0.0 \\
\hline PCY 3419 & 5.90 \\
\hline PCH 5010 & 2.4 \\
\hline PSY 4020 & 0.0 \\
\hline
\end{tabular}

Source: Field data, 2018

Table 5. Poorly-managed Courses

\begin{tabular}{|l|c|}
\hline Course Code & Attrition Rate (\%) \\
\hline PMY 3310 & 15 \\
\hline PGY 2020 & 39.5 \\
\hline PGY 2030 & 40.0 \\
\hline PGY 3010 & 20.9 \\
\hline PGY 2040 & 37.5 \\
\hline BMS 2110 & 6.2 \\
\hline
\end{tabular}

Source: Field data, 2018

\section{Views on Course Management}

i) Course Workload

The respondents in BSc Biomed stated that "the programme has too many half courses at $4^{\text {th }}$ year compared to other programmes making it difficult for us to manage to study during the final examination" and that, "Medical Physiology (PGY 2040) in the Bachelor of Biomedical Sciences and Basic and Applied Physiology (PGY 30IO) in the Bachelor of Science in Human Biology were too detailed and some concepts were unnecessary and have no application." Other courses which respondents cited as bulky included Medical Microbiology (PTM 4310) in the Bachelor of Medicine and Bachelor of Surgery, with respondents adding that, "there was no effective teaching". In Human Physiology (PGY 2020), it was claimed that, "the course is too detailed, failing to isolate things which are necessary from those which are not." ii) Pace of the Course

Neurosciences (PGY 4IIO) was one of the courses in the MBChB that was described as too fast-paced. It was also stated that, the "lecturers in Basic and Applied Physiology (PGY 30I0) do not provide deeper understanding of the concepts in the course and do not answer questions for clarification purposes from the students." In contrast, it was noted that, in Communicable and Non-Communicable Diseases (EHS 2420) and General Principles of Public Health and Environmental Health (EHS 24IO) that fall under the BSc Env. programme, "the academic staff involved gave detailed explanation of concepts and the pace was about right."

\section{iii) Level of Difficulty}

Students in the MBChB stated that "Forensic Medicine and Medical Jurisprudence (PTM 64IO) course, was not clear and ... that [a] medical lawyer [should] be engaged to teach it." Others added that "this course is not clear, there no proper lectures and there is no practical experience." Respondents in the MBChB (BSc Biology) described Basic and Applied Physiology (PGY 30IO) as one of the courses that "was too hard to understand".

\section{iv) Time Spent on the Course}

Responses to the survey questionnaire included "the Community Medicine (DPH 6024) course requires revision and re-organisation because we spend much of the time doing nothing. Less time should be allocated to this course or let it be a half course." During a focus group discussion, a respondent noted that, "in [the] Community Medicine (DPH 6024) course, projects are delayed unnecessarily by ethical approval requirements." Others stated that in the Internal Medicine Clerkship I (MED 50I0) course, "less time is allocated to Radiology and Dermatology". 
Table 6. Summary of Positives Views and Concerns about Course Management

\begin{tabular}{|c|c|}
\hline Positives & Concerns \\
\hline $\begin{array}{l}\text { In our programme (Environmental Health), the } \\
\text { course workload is manageable. }\end{array}$ & $\begin{array}{l}\text { In our programme (MBChB), we mostly do } \\
\text { not finish the content and we finish through } \\
\text { self-study. }\end{array}$ \\
\hline $\begin{array}{l}\text { Internet accessibility has improved in the } \\
\text { school. Wi-fi is accessible around the library, } \\
\text { student centre and near some hostels. }\end{array}$ & There is little open climate in the school. \\
\hline \multirow[t]{5}{*}{$\begin{array}{l}\text { The school has lecturers of good and high } \\
\text { reputations }\end{array}$} & $\begin{array}{l}\text { They are concerns from the students that in } \\
\text { some courses not all topics are covered but } \\
\text { students are told to read on their own. }\end{array}$ \\
\hline & $\begin{array}{l}\text { Time management by some lecturers is a } \\
\text { challenge. }\end{array}$ \\
\hline & $\begin{array}{l}\text { The course loads are high in most MBChB } \\
\text { courses but in the other programmes like } \\
\text { Environmental Health, Public Health and } \\
\text { Physiotherapy, most courses' loads are light. }\end{array}$ \\
\hline & $\begin{array}{l}\text { The time allocated to some courses is not } \\
\text { enough to finish all the topics in the course } \\
\text { outlines. }\end{array}$ \\
\hline & $\begin{array}{l}\text { With the introduction of new programmes } \\
\text { and courses in some programmes and } \\
\text { departments, the teaching load has increased, } \\
\text { resulting in less time for lecturers to do } \\
\text { research and be available to students for } \\
\text { consultation. }\end{array}$ \\
\hline
\end{tabular}

Source: Field data, 2018

\section{Discussion}

Biggs and Tang's (2007) theory of constructive alignment highlights the need to shift from teacher delivery to student learning. In terms of course management, educators need to design courses with the learner in mind. The four variables that should be taken into account are course workload, pace, level of difficulty and time spent on the course. Most of the student respondents $(82 \%)$ perceived the course workload to be heavy, while $71 \%$ felt that the pace at which courses were covered was very fast. This suggests that, more hours need to be allocated per week to such courses or the course content needs to be reduced. The courses cited as having heavy workloads were those that registered high examination attrition rates (Human Physiology-PGY 2020 at 39.5\%; Basic and Applied Physiology-PGY 3010 at $20.9 \%$ and Medical Physiotherapy-PGY 2040 at 37.5\%). Slotta and Linn (2009) assert that curriculum designers should undertake research to ensure that sufficient time is allocated to courses. In this study, one course (DPH 6024) was cited as having a very light workload, but much time was spent on it. This course had a zero percent examination attrition rate.

This study also revealed that $65 \%$ of the students perceived courses as difficult. Michael (2007) identified two major reasons why course content might seem difficult to students, namely, the nature of the discipline and how it relates to other fields, and how it is studied and how experts think and communicate about it. Michael (2007) adds that students perceive courses to be difficult if they cannot understand the content. In Forensic Medicine and Medical Jurisprudence (PTM 64IO), the course was described as "not clear" and it was suggested that, "a medical lawyer [be engaged to teach] it". In Basic and Applied Physiology (PGY 30I0), students perceived the course to be too hard to understand. There was a $20.9 \%$ examination attrition rate. Where students have a good understanding of the course content, examination attrition rates tend to be very low. Cherif et al. (2013) regard good understanding of the content as a general motivator that inculcates a more positive attitude among students and predisposes them to good performance.

The student participants also cited a lack of explanations and poor management of courses as factors leading to low GPA and high examination attrition rates. An example was General Pharmacognosy (PMY 33I0), which had a I5\% failure rate. The study also revealed that some concepts taught in some courses did not relate to the field of the study. For example, the pharmacology taught in Environmental Health did not relate to this field. Triola (2006) asserts that course materials which have no applicability to the field contribute to high examination attrition rates. Furthermore, some lecturers were not inducted into the School of Medicine's curriculum model and course management guidelines. The school also lacked adequate educational resources.

Courses that were regarded as well-managed had low examination attrition rates, including Psychiatry and Mental Health (PSY 64Io and PSY 4020) with no failures, Medical Biochemistry and Genetics (PGY 34I9) with a $5.97 \%$ examination attrition rate and Paediatrics and Child Health (PCH 5010 ) at $2.40 \%$. Other factors that promoted student success were clear explanations of concepts and systematic presentation of material. Based on these findings and in line with Biggs and Tang's (2007) constructive alignment theory, it is evident that when course developers keep learners in mind in terms of how heavy the courses are, the pace at which teaching takes place, the level of difficulty of the concepts to be taught and the time allocated to the courses, examination attrition rates can be low. 
This is in line with curriculum development frameworks that emphasise needs assessment which should include stakeholders. In this case, students are major stakeholders.

\section{Implications, Conclusion and Recommendations}

The study's findings confirmed a causal relationship between course characteristics and attrition rates among medical students at the University of Zambia. Poor management of courses led to high attrition rates due to student failures. With regard to the correlation between course management, the students' GPA and the School of Medicine's examination attrition rate, the workload of most courses was heavy with insufficient time allocated to thoroughly cover the syllabus. Courses were perceived to be difficult by students because lecturers did not explain concepts in depth. The failure rates tended to correspond with the extent of the perceived difficulty.

In order to address these challenges, the medical school should engage in on-going review of the curriculum and syllabus, especially with regard to course workload, level of difficulty, time allocated to cover the course and the pace at which the course progresses. Furthermore, the Department of Medical Education and Development should consider organising pedagogical training programmes for existing and newly-employed academic staff.

\section{References}

Balon, R., Alpert, J. E., Cluver, J. S., and Lewis, C. (20I3). How to get help with starting your research project: ADMSEP task force on research and scholarship. Academic Psychiatry 37(4), 22I-222.

Bateman, H. L., McCracken, G. I., Thomason, J. M., and Ellis, J. S. (20I6). Learning outcomes: Exploring implications of adopting a different level of detail. European Journal of Dental Education 6o(6), I2-30.

Bean, J. P., and Metzner, B. S. (2006). A conceptual model of non-traditional undergraduate student attrition. Review of Educational Research $55,485-540$.

Biggs, J., and Tang, C. (2007). Teaching for Quality Learning at the University. New York: Open University Press.

Billings, D.M., and Halstead, J.A. (2005). Teaching in nursing: A guide for faculty (2nd ed). Philadelphia: W.B. Sauders.

Black, P., Harrison, C., Lee, C., Marshall, B., and Wiliam, D. (2004). Working inside the black box: Assessment for learning in the classroom. Phi Delta Kappan 86(I), 8-2I.

Cherif, H., Movahedzadeh, A. F., Adams, E. G., and Dunning, J. (2013). Why do students fail? In: 2013 Annual Conference of the Higher Learning Commission A collection of papers on self-study and institutional improvement, pp. 35-51. Chicago: The Higher Learning Commission.
Curkovic, S., and Ickery, C. (2000). Quality-related action programmes: Their impact on quality performance and firm performance. Decision Sciences 31(4), 885-905

Daka, H. (20I9). Perspectives on Course Management, Teaching and Assessment of Undergraduate Programmes at the Medical School of the University of Zambia. (PhD Thesis, University of Zambia, Lusaka).

De Remer, M. (2002). The adult student attrition decision process (ASADP) model. (Doctoral dissertation, The University of Texas at Austin).

Dockter, M. (200I). An analysis of physical therapy preadmission factors on academic success and success on the national licensing examination. Journal of Physical Therapy Education 15(I), 60-64.

Frankola, K. (200I). Why online learners dropout. Workforce, October ıo, 53-63. [viewedig/08/2013]

Grant, J. (2OI2). Quality assurance systems for medical education. London: Kogan Page Ltd.

James, D., and Chilvers, C. (200I). Academic and non-academic predictors of success on the Nottingham undergraduate medical course I970I995. Medical Education, I056-1064.

Jones, R. (2008). Student retention and success: A synthesis of research. Retrieved from Higher Education Academy. www.advance-he.ac.uk

Joshi, J. (20I2). Quality Education Provision. Paris: UNESCO.

Kane, T. J., Rockoff, J. E., and Staiger, D. O. (2006). What does certification tell us about teacher effectiveness? Evidence from New York City (Working Paper I2I55). Cambridge, MA: National Bureau of Economic Research.

Kaynak, H. (2003). The relationship between total quality management practices and their effects on firm performance. Journal of Operations Management 21(4), 405-435.

Kuhn, T.S. (1996). The essential tension: Selected studies in scientific tradition and change. In: B.R. Johnson and Onwuegbuzie, A.J. (2004). Mixed Method Research: A Research Paradigm whose time has come. Educational Researcher 33(7), I4-26.

Kombo, D. K., and Tromp, D. L. (2006). Proposal and thesis writing: An introduction. Nairobi: Paulines Publications Africa, I0-45.

Mashaba, G., and Mhlongo, T. (2003). Student nurse wastage: A case study of the profile and perceptions of students of an institution. Journal of Advanced Nursing 22, 364-373.

Mirchandani, D., Lynch, R., and Hamilton, D. (2009). Using the ETS Major Field Test in business: Implications for assessment. Journal of Education for Business 77, 51-56.

Michael, J. (2007). What makes physiology hard for students to learn? Results of a survey. Advances in Physiology Education, 31(March), 34-40. 
Moore, C., and Shurock N. (2006) A strengthened community college role in teacher preparation: Improving outcomes for California. California: California University Press.

Njobvu, T. (2015). Bridging the gender gap in Zambian University Administration. LAP Lambert Academic Publishing.

Pascarella, E. T., and Terenzini, P. T. (2005). How college affects students. Vol. 2: A third decade of research. San Francisco: Jossey-Bass.

Pokorny, H., and Warren, D. (eds). (2016). Enhancing teaching practice in higher education. London: Sage.

Reason, R. D. (2009). First things first: Developing academic competence in the first year of college. Research in Higher Education 47, I49-I75.

Sarrico, S. C. (20I6). Academic Staff Quality in Higher education. Assessment \& Evaluation in Higher Education 71(2), I43-162

Schindler, L., Puls-Elvidge, S., Welzant, H., and Crawford, L. (20I5). Definitions of quality in higher education: A synthesis of the literature. Higher Learning Research Communications 5(3), 3.

Slotta, J. D., and Linn, M. C. (2009). WISE science: Web-based inquiry in the classroom. New York: Teachers College Press.

Smith, M. (2009). Using high-fidelity simulation to educate nursing students about end-of-life care. Nursing Education Perspectives, 30(2), II5-I2O.

Sulaiman, A., and Mohezar, S. (2006) Student Success Factors: Identifying Key Predictors Journal of Education for Business 81, (6), 328-333.

Susan M., David, A. W., and Deborah, L. F. (20II). Using Student and Institutional Characteristics to Predict Graduation Rates at Community Colleges. New Developments in Performance Measures and Institutional Effectiveness (35), 802-8I6.

Subedi, D. (2016). Explanatory Sequential Mixed Method Design as the Third Research Community of Knowledge Claim. American Journal of Educational Research 4(7), 570-577.

Swail, W. S. (2004). The art of student retention. A handbook for practitioners and Administrators. Austin: Educational Policy Institute.

Terry, N. (2008). The effectiveness of virtual learning in economics. The Journal of Economics and Economic Education Research 1(I), 92-98.

Triola, M. F. (2006). Elementary statistics. Reading, MA: Pearson/AddisonWesley.

Wild, L., and Ebbers, L. (2002). Rethinking student retention in community colleges. Community College Journal of Research and Practice 26, 503-5I9. 